Joanna Górecka

UAM, Poznań

\title{
OBECNOŚĆ OSOBY \\ NAUCZAJĄCEJ W ZADANIACH \\ ZORIENTOWANYCH NA \\ SAMODZIELNĄ PRACĘ UCZNIÓW W ŚRODOWISKU WIRTUALNYM
}

\section{Teacher's assistance in tasks oriented towards learners' autono- mous work in a virtual environment}

\begin{abstract}
The present paper is a report on the author's own teaching experiences and focuses on the creation of learning situations in a virtual environment. The main aim is to define the characteristics of a learning situation in such an environment. More precisely, the paper focuses on: (1) answering the question whether - and to what extent - current studies on the model of hybrid education provide the necessary information useful in developing the professional competence of teachers willing to use ICT tools in their work, and, (2) drawing conclusions about the author's own teaching experiences, whose aim is to determine what types of actions on the part of the teacher, concerning on the one hand, the task's scenario and, on the other hand, his or her intervention in a virtual environment, can contribute to learning. The article emphasizes the necessity of perceiving interaction in a virtual environment as a separate communicative situation which requires specific skills both on the part of the teacher and the learner.
\end{abstract}

\section{Wprowadzenie}

Tematem artykułu jest tworzenie sytuacji uczeniowej w środowisku wirtualnym. Przegląd specjalistycznej literatury glottodydaktycznej poświęconej nauczaniu/uczeniu się wspomaganemu przez komputer pozwala zauważyć olbrzymia różnorodność scenariuszy wirtualnych, widoczną zarówno na poziomie formułowanych przez osoby nauczające $(\mathrm{ON})$ celów dydaktycznych, w doborze na- 
rzędzi do komunikacji, jak i w sposobie definiowania przez nie zależności między działaniami komunikacyjnymi, podejmowanymi przez osoby (OU) w środowisku wirtualnym a procesami uczenia się. Równocześnie, możliwe jest dostrzeżenie różnorodnych koncepcji dydaktycznych w odniesieniu do roli osoby nauczającej w tych zadaniach online, które - poprzez swoją konstrukcję - zorientowane są na samodzielną pracę członków danej grupy uczeniowej.

Głównym celem artykułu, wokół którego organizowane są niniejsze rozważania jest dążenie do lepszego uchwycenia specyfiki sytuacji uczeniowej, jaka tworzy się w środowisku wirtualnym. W pierwszej jego części, zmierzać będziemy do ustalenia, w jakich zakresach współczesne opracowania naukowe dotyczące kształcenia w modelu hybrydowym dostarczają informacji przydatnych w rozwijaniu kompetencji zawodowych przez nauczycieli chcących wykorzystać nowe technologie w swojej pracy. Ponadto, proponowane ujęcie problemu jest dla nas możliwością podsumowania własnych doświadczeń dydaktycznych. Celem tego podsumowania jest określenie, jakiego typu działania ON, dotyczace tworzenia scenariusza zadania oraz interwencji w środowisku wirtualnym i w klasie wydają się wspomagać tworzenie sytuacji uczeniowej. Naszym zamiarem jest więc przedstawienie - w dalszych sekcjach artykułu - zmieniających się, pod wpływem badań własnych, lecz także dzięki lekturze publikacji z dziedziny nauczania wspomaganego przez komputer, reprezentacji nauczyciela-badacza w zakresie rozumienia potencjału komunikacji asynchronicznej w odniesieniu do zadania opartego na wspólnych działaniach, które OU realizuja w środowisku wirtualnym, a także w zakresie funkcji nauczyciela-tutora, towarzyszącego osobom uczącym się w sytuacji uczeniowej.

W naszych rozważaniach postulujemy konieczność postrzegania interakcji w środowisku wirtualnym jako odrębnej sytuacji komunikacyjnej, która wymaga specyficznych umiejętności zarówno od ON jak i od OU. Dyskurs edukacyjny odnosimy w niniejszym artykule do tych działań dydaktycznych ON, które wskazują na spójną koncepcję procesów nauczania/uczenia się oraz - w ścisłym odniesieniu do formułowanych w artykule rozważań - które zorientowane są na wspieranie procesów uczenia się w interakcjach asynchronicznych, zachodzących w środowisku wirtualnym.

\section{Wdrożenie hybrydowego modelu kształcenia ${ }^{1} \mathrm{w}$ polskim kontekście kształcenia językowego: wyzwania dla osoby nauczającej}

Wprowadzając temat doskonalenia zawodowego ON w zakresie pracy z wykorzystaniem nowych technologii nie sposób nie wspomnieć o wyzwaniach związanych $z$ innowacyjnym charakterem takich scenariuszy dydaktycznych. Przede wszystkim, jak podkreśla wielu badaczy, nauczyciele i uczniowie mają na ogół

\footnotetext{
$1 \mathrm{~W}$ artykule używamy wymiennie terminów mieszany i bybrydowy w odniesieniu do modelu kształcenia łączącego elementy pracy na odległości i pracy w klasie lekcyjnej.
} 
niewielkie doświadczenia praktyczne ze skutecznym (i regularnym) wykorzystaniem nowych technologii w kształceniu językowym. Jak zauważa Belisle (2010), negatywne reprezentacje nauczania wspomaganego przez komputer związane sa często właśnie z brakiem odpowiedniego pomysłu na wykorzystanie komputerów. Twierdzi ona jednocześnie, że różnorodność kontekstów dydaktycznych, w jakich udane projekty są realizowane, utrudniają uogólnianie pozytywnych aspektów takiego kształcenia. W tej sytuacji nietrudno usłyszeć dość uproszczony i krzywdzący pogląd mówiący, że komputer nie jest niezbędny, ponieważ można stawiać sobie podobne cele kształcenia nie używając nowych technologii.

Poza trudnościami natury praktycznej, związanymi z wdrożeniem scenariuszy hybrydowych, wspomnieć należy także trudności - dla nauczycieli - w budowaniu spójnych reprezentacji wiedzy w zakresie szerokiego pola glottodydaktyki, jakim jest nauczanie/uczenie się wspomagane przez komputer. Głównym wyzwaniem jest wielość badań prowadzonych w tej bardzo już rozwiniętej dziedzinie, w której wiele zagadnień jest przedmiotem złożonych i interdyscyplinarnych rozważań teoretycznych (por. np. badanie Burton i in., 2011). Jednocześnie, brak jest równolegle prowadzonych polskich badań, które umożliwiłyby szersze wprowadzenie na grunt polski nie tylko teorii i koncepcji naukowych, ale i zapewniłyby wykształcenie odpowiednio rozwiniętej terminologii ${ }^{2}$. I wreszcie, należy wspomnieć, że kształcenie w zakresie stosowania nowych technologii w edukacji językowej jest proponowane na kierunkach filologicznych zaledwie od kilku lat i nadal nie we wszystkich ośrodkach akademickich dotyczy wykorzystania narzędzi internetowych w pracy nauczyciela.

\section{Funkcje nauczyciela-tutora a nauczanie w modelu klasycznym}

W niniejszym artykule, mówiąc o nauczycielu pracującym w środowisku hybrydowym stosujemy wymiennie określenia osoba nauczajaca i tutor, za każdym razem jednakże odnosząc się do działań podejmowanych przez osobę nauczającą w przestrzeni wirtualnej. Wpisujemy się więc w argumentację proponowaną przez wielu francuskojęzycznych badaczy, między innymi Docq i Daele (2002) oraz Soubrié (2008), dla których enseignant-tutor to nauczyciel pracujący w kontekście hybrydowym; człon tutor akcentuje funkcje nauczyciela realizowane w środowisku wirtualnym. Jednocześnie należałoby podkreślić, że termin tutor uwydatnia dydaktyczne zobowiązania ON, która powinnna towarzyszyć OU - poprzez proponowane zadania i realizowane w nich cele uczeniowe - w procesach konstruowania wiedzy.

W badaniach poświęconych kształceniu na odległość wiele uwagi poświęca się pracy nauczyciela podkreślając, że realizuje on wówczas często odmienne, nowe cele dydaktyczne i że zmienia się zakres, a także forma jego obowiązków. Docq i Daele (2002), opisując rolę tutora wymieniają 4 funkcje:

${ }^{2}$ Wspomnieć należy tu jednakże o publikacji Krajki (2012). 
1. Funkcja społeczna: polega na stworzeniu przyjaznego uczniom środowiska uczenia się, między innymi poprzez budowanie sytuacji, w których procesy uczenia się są pozytywnie wartościowane. Działania te przejawiają się, między innymi, w dążeniu do scalenia grupy i we wspieraniu uczenia się we wspólpracy. Funkcja ta jest także związana z zachęcaniem uczniów do podejmowania działań w przestrzeni wirtualnej oraz z publikowaniem wspierających w swoim charakterze komentarzy dotyczacych wkładu ucznia w wykonane zadania.

2. Funkcja organizacyjna, która - w zależności od specyfiki projektu może przejawiać się między innymi w następujących działaniach: przygotowanie grafiku zadań do wykonania, zarządzanie projektem poprzez zapewnianie koniecznych zasobów i narzędzi do pracy (np. dostęp do sali komputerowej, do słowników, umieszczenie na platformie treści poleceń, itp.), dbałość o utrzymanie jasnych dla wszystkich i współdzielonych celów podczas pracy nad projektem (również poprzez werbalizowanie punktów spornych i konsensu) czy kontrolowanie przechodzenia $z$ etapu na etap w realizowanym zadaniu.

3. Funkcja pedagogiczna, zorientowana na ułatwianie procesów uczenia się $\mathrm{i}$ widoczna w podejmowaniu działań typu: zwracanie uwagi na kluczowe punkty zadania, stawianie pytań OU, zachęcanie OU do argumentowania $\mathrm{i}$ do tworzenia osobistego rozumowania, uwrażliwianie na kluczowe aspekty rozumowania i na kluczowe pojęcia w nim tworzone.

4. Funkcja techniczna, związana $z$ umiejętnością odpowiedniego doboru narzędzi i serwisów internetowych w odniesieniu do stawianych sobie celów nauczania/uczenia się oraz do specyfiki proponowanych zadań, a także - niekiedy - pomoc w korzystaniu z tych narzędzi.

Propozycja Docq i Daele (2002) była wielokrotnie rozważana i rozwijana w literaturze przedmiotu (np. Celik, 2008). W ostatnich badaniach, być może częściowo z powodu upowszechnienia się nowych technologii, a także szerszego dostępu do relatywnie prostych $\mathrm{w}$ obsłudze i niezawodnych narzędzi, coraz bardziej akcentuje się głównie wymiar pedagogiczny funkcji tutora. Ponadto, wprowadzenie na szeroką skalę do kształcenia uniwersyteckiego hybrydowych systemów kształcenia (Burton i in., 2011) pociagnęło za sobą także konieczność zapewnienia bardziej rozbudowanego zaplecza technicznego. W takiej sytuacji, nauczyciel-tutor może skupić się głównie na zarządzaniu sytuacją uczeniowa.

Z punku widzenia celów niniejszego artykułu, istotnym wydaje się także przedstawienie wyzwań dla tutora związanych z etapem wcześniejszym pracy dydaktycznej, tj. z przygotowaniem koncepcji i wdrożeniem scenariusza hybrydowego. Sytuujemy je w trzech zakresach: konstruowanie scenariusza, obecność na platformie wirtualnej oraz definiowanie ról OU i relacji w grupie. Co się tyczy pierwszego wymiaru, definiowanie koncepcji dydaktycznej i przygotowanie zadania obejmować może następujące działania: 
- krytyczną refleksję nad możliwościami nowych technologii, dobór narzędzi uwzględniający specyfikę celów dydaktycznych, lecz także przyjaznych pod względem ich obsługi;

- ustalenie odrębnych celów dydaktycznych i jednocześnie wzajemnych relacji między zadaniami realizowanymi w przestrzeni wirtualnej i w klasie;

- konieczność dokładnego przygotowania scenariusza zajęć, przewidywania roli $\mathrm{ON}$, ról OU oraz ich wzajemnych relacji i odpowiedzialności (wymiar projektowy pracy).

W kategorii „wyzwania związane z zarządzaniem sytuacją komunikacyjną i uczeniową online" wymienić należy następujące działania nauczyciela:

- dostrzeganie i różnicowanie specyfiki interakcji w środowisku wirtualnym i w interakcjach bezpośrednich;

- umiejętność zarządzania komunikacją online, zwłaszcza w zakresie rozwijania działań kognitywnych wyższego rzędu (por. Ellis i in., 2006);

- rozwijanie umiejętności współpracy u OU oraz podejmowanie działań zmierzających do budowania wspólnoty uczeniowej;

- organizowanie pracy w formie projektu; przez wymiar projektowy zadania rozumiemy sytuację dydaktyczna, w której OU samodzielnie i wspólnie wykonują zadanie i są odpowiedzialni za produkt końcowy;

- twórcze dostosowywanie scenariusza tak, by możliwe było uwzględnienie nie tylko trudności OU, lecz także ich oczekiwań;

- ocenianie pracy OU: ocena dotyczy rezultatu końcowego, lecz może także uwzględniać działania uczeniowe podejmowane podczas wykonywania zadania (np. współpraca między członkami grupy, odpowiedzialność indywidualna za wykonanie danego etapu zadania itp.).

Ostatnia kategoria akcentuje odmienną jakość relacji z OU, wynikająca z nowych potrzeb i oczekiwań ze strony uczących się, lecz także nauczyciela:

- uwzględnienie reprezentacji, potrzeb i oczekiwań OU w zakresie roli $\mathrm{ON}$ i OU;

- zarządzenie wymiarem społeczno-afektywnym procesów uczenia się;

- wspieranie/rozwijanie umiejętności technicznych u OU;

- w wielu zadaniach, także wspieranie/rozwijanie umiejętności informacyjnych u OU.

Powyższe listy umiejętności i działań pozwalają zauważyć, że zadania nauczyciela-tutora pracującego $\mathrm{w}$ modelu mieszanym wykraczaja poza funkcje zwyczajowo wymieniane w literaturze przedmiotu w odniesieniu do tzw. modelu tradycyjnego. Wyzwaniem jest wynegocjowanie z OU kontraktu uczeniowego w sytuacji nauczania/uczenia się mieszanego, ze względu na odmienność sytuacji dydaktycznej, lecz także często większe wymagania formalne i intelektualne zadania. Wymagania formalne związane są na przykład z koniecznościa podejmowania określonych działań uczeniowych na tych etapach zadania, które nie są 
przedmiotem kontroli nauczyciela w tradycyjnym modelu kształcenia (np. przygotowanie do dyskusji ustnej). Z kolei wymagania intelektualne moga dotyczyć, na przykład, konieczności przejęcia przez OU odpowiedzialności za przebieg interakcji podczas dyskusji na forum.

Specyfika pracy ON w środowisku wirtualnym uzasadnia wielość badań zmierzających do weryfikacji zasadności modelu hybrydowego (najczęściej jednak sa to publikacje zachwalające ten model kształcenia) oraz do określania warunków progowych dla tworzenia sytuacji uczeniowej online. W dalszej części artykułu skupimy się na określeniu, w jaki sposób w badaniach tych ujmowana jest obecność ON.

\section{Definiowanie roli i zadań nauczyciela-tutora we współczesnych badaaniach glottodydaktycznych}

W niniejszej sekcji przytoczymy wybrane przykłady badań empirycznych, prowadzonych w obrębie interesującego nas pola badawczego, jakim jest nauczanie/uczenie się wspomagane przez komputer. Wykorzystane w tym zestawieniu publikacje pozwalają, po pierwsze, dostrzec różnorodność aspektów związanych z pracą nauczyciela-tutora, po drugie zaś umożliwiają wypracowanie bardziej precyzyjnych kryteriów doboru publikacji czyli bardziej skuteczne określenie, jaki typ pytań badawczych i jakie ujmowanie sytuacji uczeniowej może stanowić osadzenie teoretyczne dla interesujących nas problemów badawczych.

Wybranym kontekstem jest dla nas sytuacja komunikacyjna, w trakcie której OU prowadza, za pomocą narzędzi do komunikacji asynchronicznej (forum, wiki), interakcje zorientowane na tworzenie wiedzy, tj. podejmują działania komunikacyjne i intelektualne warunkujące, bądź też ułatwiające procesy refleksji indywidualnej i grupowej. Interakcje tego typu realizują się najczęściej w zadaniach o charakterze argumentacyjnym, takich jak dyskusja na forum czy wspólne przygotowywanie notatek, na podstawie których przygotowana zostanie następnie prezentacja ustna. Spośród prowadzonych badań, zorientowanych na analizę interakcji uczeniowych w przestrzeni wirtualnej, szczególnie wartościowe dla określania wyzwań koncepcyjnych i praktycznych związanych z kształceniem poprzez działania na platformie internetowej wydają się te badania, które ujmuja procesy uczenia się z perspektywy nauczyciela-badacza proponującego dany scenariusz dydaktyczny online (por. np. Weasenforth i in., 2002; Meyer, 2006; Hanna i de Nooy, 2009) jak i te, które koncentrują się na określeniu sposobu, w jaki osoba ucząca się definiuje przedmiot uczenia się oraz działania, jakie powinna ona - w swoim mniemaniu - podejmować podczas wykonywania zadania (por np. Ellis i in., 2006).

Jednakże, jak już zostało podkreślane, obecność ON ujmowana jest we współczesnych badaniach glottodydaktycznych w bardzo różny sposób, ponieważ badacze różnie definiują funkcje ON i cele zadań online. Zauważyć więc należy, że wymienione poniżej problemy $\mathrm{i}$ wątki poruszane $\mathrm{w}$ literaturze przedmiotu nie moga być postrzegane jako wyczerpująca lista problematyki związanej z kształce- 
niem w kontekście hybrydowym. Proponowana lista ma charakter arbitralny i z pewnością jest niekompletna. Odzwierciedla ona nasze indywidualne próby uporządkowania literatury przedmiotu, określenia możliwości czerpania z istniejących publikacji przez nauczyciela-badacza, wdrażającego innowacyjny (Charlier i in., 2006) scenariusz dydaktyczny i zmierzającego do wykorzystania nie tylko ustaleń teoretycznych poczynionych w dziedzinie nauczania/uczenia się wspomaganego przez komputer, lecz także już istniejących wdrożeń.

Zauważyć także należy, że postrzeganie aspektów wspólnych dla badań prowadzonych w dziedzinie nauczania/uczenia się wspomaganego przez komputer jest też trudne dlatego, że opracowania naukowe nie zawsze zawieraja informacje pozwalające dobrze zrozumieć kontekst instytucjonalny, w które wpisuje się dany kurs. Ponadto, także stopień hybrydyzacji kursu, tj. procentowa zależność między zajęciami prowadzonymi online i w klasie, może być różny (por. Charlier i in., 2006). Proponujemy niniejszym następujące zestawienie wybranych aspektów badawczych dotyczących obecności ON w zadaniach zorientowanych na konstruowanie wiedzy i osadzonych w środowisku wirtualnym:

1. Konceptualizowanie roli ON i roli instytucji edukacyjnych w nowej rzeczywistości edukacyjnej i spotecənej. W kategorii tej wymienić należy publikacje o charakterze teoretycznym (por. np. Walckiers i de Praetere, 2004; Palloff i Pratt, 2007; Gajek, 2008), zorientowane na zilustrowanie potencjału wybranych narzędzi w świetle aktualnie dominujących teorii uczenia się (uczenie się w dyskusji, społeczny wymiar konstruowania interakcji). Obecne są tam także odwołania do specyficznych pojęć opisujących wirtualny kontekst nauczania/uczenia się, takich jaki wspólnoty uczeniowe czy indywidualne środowisko uczenia sie (fr. environnement d'apprentissage personnel). W grupie tej należy też, naszym zdaniem, umieścić badania akcentujące zmieniającą się rolę nauczyciela poprzez podejmowanie tematów, takich jak: rola komputerów i Internetu w życiu uczniów, współczesne formy komunikacji i przestrzeni społecznej, rola szkoły w dzisiejszym świecie itp.

2. Badania $w$ dialataniu, przedstawiajace ocene proponowanych zadań $i$ scenariuszy, dokonana prezez ON i/ lub OU. W kategorii tej wymienić możemy badania w działaniu, prowadzone przez ON i dotyczace własnej praktyki dydaktycznej, mające na celu udoskonalenie koncepcji dydaktycznej, na przykład poprzez analizę interakcji ON-OU oraz opis strategii działania OU (Weasenforth i in., 2002; Hanna i de Nooy, 2010). W tę kategorię wpisują się też badania zorientowane na uzyskanie, od samych uczniów, oceny proponowanej koncepcji kursu i scenariusza (Soubrié, 2008).

3. Oczekiwania $O N$ zwiazane z.praca online: potencjat zadań online w rozwijaniu samodzielności uczeniowej $i$ kompetencji interkulturowej. Wymienić możemy tu badania Hanna i de Nooy (2009), u podstaw których leży teza zakładająca, że rozwijane kompetencji interkulturowej u OU jest jednym z podstawowych celów, jakie nauczyciel powinien formułować w zadaniach interakcji online, zorientowanych na osiaganie samodzielności komunikacyjnej. 
4. Formutowane przez ON cele dydaktyczne a decyzje dotyczqce doboru narzedri. Do grupy tej należą badania, w których autorzy wiążą refleksję dotyczącą specyfiki narzędzia z celami uczeniowymi, jakie uczeń miałby realizować w danym scenariuszu dydaktycznym. Wspomnieć możemy tu pracę Groves i O'Donoghue (2009), argumentujących przydatność wiki na etapie przygotowania zadania indywidualnego i pracę Hanna i de Nooy (2009), zawierająca pogłębione rozważania dotyczące możliwości wykorzystania forum jako przestrzeni do dyskusji.

5. Oczekiwania ON wobec driatań, jakie OU powinni podejmować w scenariuszach online. Badania $\mathrm{z}$ tej kategorii koncentrują się na identyfikowaniu, w odniesieniu do określonych teorii uczenia się tych działań OU realizowanych w środowisku wirtualnym, które mogą mieć wymiar uczeniowy. Wspomnieć można tu badanie Chen i Hung (2002) dotyczące optymalizacji funkcji forum jako narzędzia umożliwiającego dyskusję asynchroniczna, a także badanie Ellis $i$ in. (2006), w którym autorzy opisuja główne typy działań komunikacyjnych i uczeniowych, jakie OU podejmują w środowisku wirtualnym i koreluja je następnie ze sposobem, w jaki OU definiuja przedmiot uczenia się - a także proces uczenia się - online i w klasie.

6. Badania opisujace i badajace crynności ON online: typ i cel zadan online $i$ skuteczność dydaktyczna procesón nauczania/uczenia sie zachodzacych w tym kontekście. W tej kategorii umieszone zostały badania, które nie są inicjowane przez ON. Są do badania opisujące istniejące zachowania $\mathrm{ON}$ w środowisku wirtualnym; wnioski mogą być formułowane w sposób opisowy lub też - w przypadku badań zorientowanych na udoskonalenie praktyki nauczycielskiej - krytyczny. I tak, czynności tutora w scenariuszu mieszanym moga być, tak jak u Degache i Nissen (2008), postrzegane jako jeden z parametrów opisywanej sytuacji dydaktycznej, rozgrywanej częściowo w klasie i częściowo online. O podejmowanych przez ON działaniach można wnioskować wówczas pośrednio, poprzez analizę proponowanych form pracy, celów zadań i ocen stosowanych w odniesieniu do mieszanego sytemu kształcenia. Jednocześnie należy wspomnieć, że w cytowanym badaniu Degache i Nissen (2008) decyzja o podjęciu działań dydaktycznych w modelu hybrydowym nie jest motywowana - w pierwszym rzędzie indywidualną decyzją ON, lecz wynika ze zmian w koncepcji kształcenia formułowanych na poziomie instytucji. W tej kategorii wspomnieć także należy badania dotyczące dydaktyki przedmiotowej (np. projekt Le français en 1ère ligne, którego celem jest przygotowanie przyszłych nauczyciel j. francuskiego jako obcego do nauczania na odległość lub w scenariuszach mieszanych ${ }^{3}$ ), tj. zorientowanych na określenie wyzwań dydaktycznych stawianych przed nauczycielem konstruującym zadania online i zarządza-

${ }^{3}$ Informacje na temat projektu Le Français en première ligne dostępne są pod następującym adresem: http://w3.u-grenoble3.fr/fle-1-ligne/objets_recherche.php [DW: 30.11.2011]. 
Obecność osoby nauczającej w zadaniach zorientowanych na samodzielna pracę...

jącym pracą OU podczas ich wykonania. Skuteczność działań ON mierzona jest ocena przygotowanego przez niego zadania czyli jego dostosowaniem do specyfiki kształcenia online (np. Mangenot i Penilla, 2007).

7. Badania teoretyczne, dotyczace ksztatcenia w modelu bybrydowym jako oferty edukacyjnej. Wspomnieć należy tu europejski projekt badawczy HySup (realizowany w latach 2009-2012)4, którego celem jest lepsze zrozumienie wpływu hybrydowego systemu kształcenia (fr. dispositif hybride) na: (1) procesy uczenia się, (2) formy i sposoby nauczania oraz (3) instytucje szkolnictwa wyższego. Badania prowadzone są w oparciu o wypracowaną w projekcie typologię hybrydowych systemów nauczania/uczenia się, która zakłada istnienie 6 typów tychże modeli kształcenia w szkolnictwie wyższym.

Proponowane zestawienie pozwala zauważyć, że obecność ON może być opisywana w perspektywie osobistej (ON prowadzi badanie w działaniu, np. Soubrié, 2008) lub też analizowana w szerszym kontekście instytucjonalnym, na podstawie praktyki zawodowej, współdzielonej przez kilku (bądź przez większą grupę) nauczycieli. W tym drugim przypadku, badania wykorzystują często elementy metodologii ilościowej (Degache i Nissen, 2008; Burton i in., 2011).

Przytoczone powyżej problemy badawcze, leżące u podstaw wybranych badań prowadzonych w dziedzinie nauczania/uczenia się hybrydowego pozwalaja zauważyć różnice między koncepcjami dydaktycznymi (między innymi w zakresie roli i odpowiedzialności uczestników procesu dydaktycznego) oraz w sposobach definiowania przedmiotu uczenia się. Zauważyć można także różnice w decyzjach dotyczących doboru narzędzi do pracy w środowisku wirtualnym oraz różnice przy określaniu sposobu ich wykorzystania w proponowanych zadaniach. Podsumowując, czynnikami różnicującymi w scenariuszach proponowanych w środowisku wirtualnym i opartych na komunikacji asynchronicznej okazują się być następujące elementy:

- kwestia ciagłości miedzy kontekstem stacjonarnym a online: w obu kontekstach mogą być proponowane odrębne zadania, bądź też praca online i stacjonarna moga stanowić etapy jednego zadania;

- miejsce pracy online w postrzeganiu koncepcji kursu i nawiązywanie (lub też brak odniesień) do pracy online podczas spotkań bezpośrednich, tj. zajęć w klasie;

- kwestia wliczania wyników pracy online do oceny końcowej kursu: praca online może być definiowana jako zadanie fakultatywne lub jako zadanie oceniane;

- kryteria oceny proponowane wobec zadań realizowanych w przestrzeni wirtualnej; dwoma skrajnymi przypadkami wydają się być: (1) scenariusz dydaktyczny, w którym ocena końcowa OU zależy od jego obecności na platformie oraz (2) zadanie, w którym kryteria oceny odzwierciedlaja oczekiwania wobec typu działań intelektualnych, jakie powinny podejmować osoby uczące się podczas pracy online;

${ }^{4}$ Internetowa strona projektu: http://hy-sup.eu [DW: 30.11.2011]. 
- kontrola/wsparcie ON podczas pracy online; elementy różnicujące dotycza, na przykład, udziału $\mathrm{ON}$ w interakcjach prowadzonych przez $\mathrm{OU}$, a także celów jego interwencji, która może zmierzać do wspierania działań uczeniowych, lub też być reaktywna, tj. ON może ograniczyć swoje interwencje jedynie do sytuacji, w których uczestnicy skonfrontowani są w problemem natury technicznej bądź uczeniowej, bądź też do sytuacji, kiedy taka potrzeba sygnalizowana jest bezpośrednio przez OU;

- możliwości tworzenia wspólnoty uczeniowej w scenariuszu zadania online (zadania nastawione na współdziałanie lub na współprace);

- kwestia oceny pracy własnej OU, ti. decyzje dotyczące sposobu oceniania pracy OU online, a także znaczenia, jakie przypisuje się jego określonej aktywności (np. czy zakłada się, ze cześć działań/refleksji jest nieuchwytna online; czy ocenia się tylko podsumowanie, wynik końcowy zadania?);

- doświadczenie OU w zakresie korzystania z proponowanych narzędzi wirtualnych i charakter wcześniejszych doświadczeń (czy są to doświadczenia uzyskane w kontekście instytucjonalnym, czy też oparte są na ich indywidualnej praktyce?);

- doświadczenie ON w pracy w modelu mieszanym: doświadczenie to może dotyczyć praktyki zawodowej lub też odnosić się do okresu, kiedy nauczyciel był jeszcze uczniem; ponadto, doświadczenie może być wynikiem specjalistycznych szkoleń, bądź też może być uzyskane w toku samodzielnego wprowadzania innowacji dydaktycznych (nauczyciel-samouk);

- kwestia indywidualnej realizacji kursu a wierności modelowi; różnice te pojawiają się w sytuacji, kiedy osoba prowadząca zadania online jest jednocześnie autorem kursu lub też prowadzi kurs przygotowany przez innego nauczyciela, bądź też, kiedy jest ona jedną z kilku osób pracujących wspólnie z dużą grupą studentów;

- przygotowanie kursu: kryterium to odnosi się do różnych typów innowacji (Charlier i in., 2006) i dotyczy szerokiego spektrum kursów, począwszy od kursów autorskich, rewolucjonizujących nawyki studentów i wymagających wdrożenia do koncepcji pracy i stosowanych technologii, a skończywszy na kontekstach instytucjonalnych, w których mieszany model nauczania jest ogólnie przyjętą koncepcją dydaktyczną;

- prowadzenie kursu (kurs prowadzony przez jednego nauczyciela, lub też projekt grupowy, niekiedy współprowadzony przez różne instytucje).

Wymienione różnice pokazują, naszym zdaniem, złożoność pola badawczego, jakim jest nauczanie wspierane przez komputer, a także podkreślają wielość i złożoność decyzji dydaktycznych, jakie ON musi podjąć przy tworzeniu koncepcji kursu hybrydowego.

Nauczyciel podejmujący się konstruowania zajęć w modelu hybrydowym zauważyć może, że w dziedzinie naczania/uczenia się wspomaganego przez komputer, podobnie jak w całej dydaktyce języków obcych, wciąż zbyt mało jest 
rzetelnie prowadzonych badań jakościowych, zaprojektowanych nie tylko jako pilotaż, lecz jako rozłożone w czasie badanie, które ukierunkowane byłoby na rozwiązywanie w praktyce konkretnych, typowych dla modelu hybrydowego problemów dydaktycznych. Dlatego też pomocne w budowaniu indywidualnej kompetencji zawodowej wydaje się prowadzenie własnych badań. Koniecznym wydaje się także konsultowanie opracowań syntetyzujących istniejące badania $\mathrm{i}$ dążących do uporządkowania ukonstytuowanej już wiedzy dotyczącej różnych aspektów nauczania/uczenia się online, a także samodzielne dążenie ON do porządkowania wiedzy w tym zakresie.

\section{Sprawozdanie $z$ badania $w$ działaniu: reprezentacje $O N$ a projek- towanie badania glottodydaktycznego}

We wcześniejszych częściach artykułu przedstawione zostały główne wątki badań prowadzonych w dziedzinie nauczania/uczenia się wspomaganego przez komputer i dotyczących pracy ON. W niniejszej sekcji, naszym celem będzie przedstawienie wybranych wniosków z własnych doświadczeń dydaktycznych, tj. krytyczna ocena samodzielnie wypracowanych scenariuszy zadań hybrydowych oraz omówienie wstępnych oczekiwań dotyczących zasadności proponowania zadań wykorzystujących narzędzie wiki w kontekście kształcenia zorientowanego na rozwijanie sprawności argumentacyjnych u studentów kierunków filologicznych. Zakładamy, że postrzeganie zadania online jako potencjalnie wartościowego wiąże się z koniecznością specyficznego określenia roli, jaką ON powinna wypełniać na tym etapie scenariusza, a także, że oczekiwania wobec funkcji ON odzwierciedlaja reprezentacje ON w zakresie organizowania i zarządzania tą sytuacją uczeniowa (pytanie 1.). Jednocześnie, wnioski formułowane w oparciu o nasze doświadczenia, konfrontowane będą z wnioskami płynącymi z krytycznej lektury istniejących publikacji w interesującej nas dziedzinie. Naszym kolejnym celem jest bowiem określenie, w jakim zakresie istniejące publikacje przyczynić się mogą do budowania skutecznych reprezentacji dotyczących procesów nauczania/uczenia się w środowisku wirtualnym, tj. w jakim zakresie moga być wykorzystane przez ON chcące doskonalić swoje kompetencje zawodowe poprzez rozszerzenie środowiska pracy o przestrzeń wirtualną (pytanie 2). Podsumowując, poniższe rozważania formułowane są w odniesieniu do następujących pytań:

1) w jaki sposób ewoluowały reprezentacje ON dotyczace jej funkcji na etapie przygotowania i prowadzenia zadań w scenariuszu mieszanym, zorientowanym na rozwijanie sprawności argumentacyjnych w języku obcym? (sekcja 5.2.);

2) w jakim zakresie literatura przedmiotu podejmuje temat uczenia się w dialogu podczas interakcji asynchronicznych i jakich zakresach wnioski z opublikowanych badań mogą być wykorzystane w naszej praktyce dydaktycznej (sekcja 5.3.)? 


\subsection{Przyjęte założenia oraz przebieg badania własnego}

Celem badawczym realizowanym podczas badania pilotażowego było określenie, w jaki sposób działania ON mogą wspomóc pracę OU na wiki tak, by podejmowane $\mathrm{w}$ tej wirtualnej przestrzeni działania sprzyjały rozwijaniu samodzielności uczeniowej i komunikacyjnej OU. Zadaniem proponowanym OU była dyskusja ustna w klasie. Praca na wiki miała wspomóc refleksję grupowa nad tematem rozwijanym w dyskusji, czyli budowanie wiedzy w określonej dziedzinie, a także nabywanie niezbędnego słownictwa. Zgodnie z koncepcja zadania, wymiar współdziałania polegał na współnegocjowaniu tematu, a także na wspólnym dążeniu do jego argumentacyjnego ujęcia.

Poniżej przedstawimy najistotniejsze - w naszym mniemaniu - cechy wiki, wskazujące na wartość tego narzędzia w zadaniach opartych o interakcje między OU (Górecka, 2009):

- dzięki pracy na wiki, proces nauczania może koncentrować się także na etapach dotąd pomijanych (planowanie, samoocena) i dotyczyć działań dotąd trudno dostępnych dla nauczyciela (praca w grupach);

- scenariusz zadania daje możliwość zaangażowania w interakcję większej liczby osób: sprzyja więc aktywności uczniów oraz przejmowaniu przez nich osobistej odpowiedzialności za realizowane zadanie;

- możliwe jest budowanie bardziej partnerskich relacji interpersonalnych, ponieważ wypowiedź na wiki powinna być rzeczowa, zaś rozmówcy powinni rzeczywiście współpracować przy wypracowywaniu wspólnych rozwiazzań;

- zadania moga promować rozwijanie działań kognitywnych wyższego rzędu; pisemna forma wypowiedzi może sprzyjać budowaniu pogłębionej i uargumentowanej refleksji, opartej na standardach myślenia krytycznego.

- możliwe jest bardziej staranne dokumentowanie się, czyli poszukiwanie informacji, merytoryczna ocena jej zawartości oraz ocena jej przydatności w odniesieniu do celów poznawczych, jakie stawia sobie grupa.

Zauważyć należy, że wiki nie zapewnia przestrzeni do interakcji prowadzonych w formie dyskusji. Ze względu na ograniczoną możliwość negocjacji znaczeń (trudno jest prowadzić na wiki rozmowę tak, jak dzieje się na forum), sprzyja raczej budowaniu refleksji własnej, wspartej uwagami i komentarzami pozostałych członków grupy i rozwijanej przy ich uwzględnieniu. Dlatego też jest narzędziem dostosowanym do tych hybrydowych scenariuszy, które zakładają konieczność wprowadzenia określonych działań negocjacyjnych także podczas pracy w klasie, tj. w kontekście stacjonarnym.

Badanie objęło studentów II roku studiów licencjackich, podczas zajęć trwających 1 semestr. Studenci pracowali w grupach 3-4 osobowych. Zadaniem grup było przeprowadzenie dyskusji w klasie, trwającej ok. 60 minut. Studenci sami wybierali temat dyskusji, zaś praca na wiki służyła lepszemu przygotowaniu do prowadzenia interakcji w klasie i zmierzała do wynegocjowania tematu, a 
także zaproponowaniu pytań, które prowadzący dyskusję mogli zadawać w czasie jej trwania tak, by, zorientować współtworzoną refleksję ku określonym problemom, a także by wspomóc OU w budowaniu odpowiednio szerokiego rozumienia dyskutowanych treści, głównie poprzez sprawne łączenie faktów, a także interpretacji i rozumowania formułowanego przez innych rozmówców z własnymi przemyśleniami i argumentami.

Przygotowanie do zadania dyskusji rozpoczynało się dwa tygodnie wcześniej, a wymiernym wynikiem pracy własnej studentów na wiki powinien być sformułowany w formie pytania temat dyskusji oraz lista zagadnień problemowych traktowanych jako lista wątków i aspektów, które mogą być w niej poruszone. Funkcja zadania polegającego na formułowaniu pytań jest więc dwojaka:

1) przygotowanie zadania dyskusji w klasie, umożliwiające następnie sprawne stworzenie i zarządzanie sytuacją komunikacyjną; pytania maja umożliwić rozpoczęcie dyskusji i jej odpowiednie dynamiczne prowadzenie, na przykład dzięki przygotowaniu odpowiedniego słownictwa;

2) zaprojektowanie interakcji jako rzeczywiście argumentacyjnej sytuacji, w której rozmówcy krytycznie wyrażają nie tylko swoje doświadczenia i poglądy, lecz także odnoszą w sposób uporządkowany i krytyczny do dyskursu publicznego (tj. opierają się na faktach, lecz także na stanowiskach argumentacyjnych formułowanych przez określone grupy społeczne itp.).

Drugi z formułowanych celów zorientowany jest na rozwijanie umiejętności i postaw, które nie zawsze są przedmiotem doskonalenia w kontekście szkolnym: przyjęte założenie zakłada, że interakcja asynchroniczna umożliwić może budowanie pogłębionej i bardziej dialogowej refleksji, i tym samym przyczynić się do budowania jakościowo nowej sytuacji uczeniowej podczas realizacji zadania dyskusji w klasie.

W procesie zbierania i analizowania danych, ON wykorzystywała zapis pracy własnej OU na wiki (analiza dyskursu), a także prowadziła dzienniczek badacza.

\subsection{Wnioski formułowane na podstawie danych uzyskanych $\mathrm{w}$ badaniu własnym: ewolucja reprezentacji $\mathrm{ON}$ dotyczących jego roli w zadaniach online}

$\mathrm{Na}$ etapie przeprowadzonego pilotażu, refleksja nad rolą ON formułowana była głównie w odniesieniu do trudności, jakie nauczyciel-tutor dostrzegał w tworzeniu i w zarządzaniu sytuacją uczeniową online. Niemalże nieobecny na tym etapie był wymiar poznawczy interakcji na wiki, a także dyskursywny aspekt wykonywanych działań, czyli regularne korelowanie etapu zadania wykonywanego na wiki z rozwijaniem sprawności mownych. I tak, pośród głównych trudności dotyczących zadań ON i wynotowanych w dzienniczku badacza wymienić można:

1. Konstrukcje scenariusza. Wspomnieć możemy tu między innymi problem odpowiedniego rytmu pracy OU na wiki (na przykład studenci nie zawsze przestrzegali narzuconych ram czasowych dla poszczególnych eta- 
pów pracy) czy też wyzwania związane z budowaniem postawy wzajemnej odpowiedzialności za publikowane treści (na przykład część umieszczonych na wiki danych nie była w żaden sposób weryfikowana ani oceniana przez pozostałych członków grupy).

2. Odpowiednie definiowanie $i$ wykorzystanie potencjalu narzedzia. Nauczycielbadacz wielokrotnie mógł zauważyć, że OU nie są przyzwyczajeni do pracy opartej na współdziałaniu (fr. apprentissage collaboratiff; ich strategie polegały raczej na podziale odpowiedzialności, tj. wyznaczeniu prac cząstkowych, za które odpowiedzialność ponosiła tylko jedna osoba: produkt finalny był wówczas sumą działań indywidualnych, nisko skoordynowanych i nie podlegających wspólnej, krytycznej ocenie końcowej.

3. Wspomaganie/wspóttworzenie sytuacji uczeniowej przez ON. Jednym z najważniejszych wniosków wydaje nam się konieczność takiego skonstruowania scenariusza, które umożliwiłoby ON efektywną kontrolę dydaktyczną nad działaniami podejmowanymi na wiki oraz regularne wsparcie dla działań OU. Sądzimy, że jednym ze skuteczniejszych rozwiązań jest dzielenie w większym niż dotychczas stopniu odpowiedzialności za realizowane zadanie z OU, na przykład wyznaczając wybranych studentów odpowiedzialnymi za odpowiednie wykonanie poszczególnych etapów pracy. Podobnie, koniecznym wydaje się dokładne przygotowanie ON do prowadzenia zadania opartego na aktywności własnej OU; jedna z zaobserwowanych przez ON trudności było przeprowadzenie skutecznej interwencji dydaktycznej tak, by nie była ona odczytana jako zagrażająca twarzy przez OU, co wiązało się, na przykład, z koniecznością ograniczenia uwag krytycznych do jednego, najistotniejszego spośród zaobserwowanych problemów. Kolejnym wyzwaniem było także precyzyjne formułowanie swoich uwag i oczekiwań, aby mogły zostać odczytane jako rzeczowe wskazówki przez OU.

4. Reprezentacje OU dotyczqce przedmiotu uczenia sie. Wprowadzenie scenariuszy hybrydowych wiąże się niejednokrotnie z koniecznością przedefiniowania celów kształcenia oraz jego treści. W przypadku zadań rozwijających sprawności mowne, jednym z najważniejszych wyzwań dla ON okazała się konieczność uzasadnienia potencjału pracy pisemnej dla formy wypowiedzi ustnej oraz uzasadnienia znaczenia działań dążących do negocjacji treści dla jakości współtworzonej argumentacji.

Powyższe aspekty, ujęte w dzienniczku badacza nie zawsze mogły zostać stać się przedmiotem odpowiednio zaprogramowanej interwencji dydaktycznej. Zważywszy na fakt, że refleksja ON prowadzona była równolegle z działaniami dydaktycznymi realizowanymi w obrębie innowacyjnego scenariusza, na tym etapie wdrożenia projektu hybrydowego praca w środowisku wirtualnym nie była przedmiotem oceny. Celem ON było umożliwienie OU zapoznania się z narzędziem i nową formą pracy, zaś rozmowy wokół zadań realizowanych online dotyczyły głównie wsparcia organizacyjnego i technicznego. Tego typu tenden- 
cja w procesie nabywania doświadczenia zawodowego ON sygnalizowana jest także w literaturze przedmiotu: wielu badaczy podkreśla, że aspekty techniczne i organizacyjne dominują w pierwszych latach pracy w środowisku wirtualnym.

Przeprowadzone badania pozwalają zauważyć konieczność uporządkowania własnej refleksji na temat wartości uczeniowej interakcji zachodzacych w środowisku wirtualnym, co możliwe jest również dzięki konsultacji literatury przedmiotu. Wnioski nauczyciela-badacza, dotyczące badań pilotażowych budowane są więc także na podstawie wniosków płynących z krytycznej lektury publikacji naukowych. W kolejnej sekcji przedstawimy wybrane badania, których autorzy podejmowali się realizacji zbliżonych celów dydaktycznych. Naszym zamiarem będzie wskazanie, w jakich zakresach wnioski formułowane w tychże badaniach mogą być przydatne w naszej praktyce nauczyciela-badacza.

\subsection{Przestrzeń komunikacyjna online jako przestrzeń uczeniowa a wyzwania dydaktyczne dla ON. Wnioski formułowane na podstawie literatury przedmiotu}

Decydując się na przywołanie wybranych badań, dotyczących interesujących nas aspektów pracy ON w środowisku wirtualnym, chcielibyśmy określić wartość wniosków formułowanych przez innych autorów dla doskonalenia własnej praktyki dydaktycznej. Przegląd literatury przedmiotu pozwala zauważyć, że wielu badaczy, również w kontekście kształcenia stacjonarnego, wskazuje na trudności związane $z$ tworzeniem zadań opartych na samodzielnej pracy OU i na ich relatywnie niską skuteczność dydaktyczną. Niewiele jest jednak prac, w których podejmowana jest próba rozwijania umiejętności uczenia się w interakcji. Oceniamy więc, że jeden z kluczowych naszym zdaniem aspektów badawczych w dziedzinie nauczania/uczenia się wspomaganego przez komputer, tzn. procesy uczenia się we współdziałaniu, jest ciagle niedostatecznie wyeksponowany. Podkreślić jednakże należy, że owo zorientowanie wielu badań na metodyczne aspekty procesu nauczania/uczenia się wynikać może częściowo z samej orientacji poznawczej autorów, którzy często nie umieszczają kwestii dydaktycznych w centrum swoich zainteresowań.

Zapoznanie się z literaturą przedmiotu pozwoliło nam także dostrzec, że w większości badań funkcje tutora definiowane się i analizowane raczej w odniesieniu do tworzenia i zarządzania sytuacją uczeniowa, i że stosunkowo mało obecne w literaturze przedmiotu są badania skupione na określaniu specyfiki działań ON zorientowanych na wspieranie procesów konstruowania wiedzy przez OU i na uchwyceniu zależności między działaniami ON a działaniami uczeniowymi, które OU podejmują na platformie. Podobnie, procesy konstruowania wiedzy analizowane są raczej w odniesieniu do autonomicznego zadania, realizowanego w całości online i definiowanego jako osobna część kursu, jak na przykład rozmowa na forum. I wreszcie, zadania online kładą na ogół nacisk na pracę projektową OU, akcentują więc produkt końcowy, często rozumiany w 
sposób dość szeroki: na przykład dyskusja ma przyczynić się do „lepszego zrozumienia określonego problemu naukowego lub praktycznego, właściwego dla danej dziedziny". Przegląd literatury przedmiotu pozwala także zauważyć, że badacze nadają różne znaczenie opisywanym elementom interakcji między uczniami i stosuja różne kryteria oceny w odniesieniu do realizowanych w nich działań komunikacyjnych i uczeniowych. Przypuszczamy, że jest to związane między innymi z funkcja, jakie dane zadanie pełni w całej koncepcji kursu, a także z tematyką poruszaną w interakcji i jej wyzwaniami intelektualnymi i komunikacyjnymi (zadanie może na przykład być argumentacyjne lub zorientowane na rozmowę i wymianę myśli, może dotyczyć tematów codziennych lub wymagać od uczestników wyspecjalizowanej wiedzy, może być krótkim etapem lub też stanowić główny człon zadania online, może być dla rozmówców doświadczeniem punktowym bądź cyklicznym).

Poniżej przedstawimy dwa istotne wnioski, formułowane w literaturze przedmiotu, które wzbogacają naszą - jako nauczyciela-badacza - wiedzę dotycząca zarządzania interakcjami o charakterze uczeniowym.

Wniosek 1: Konieczność rozwijania umiejętności ucz̧enia sie w grupie, a także wspólnego budowania odpowiednich reprezentacji przedmiotu uczenia sie.

Wniosek ten formułujemy między innymi na podstawie krytycznej lektury badania przeprowadzonego przez Groves i O’Donoghue (2007). Przedstawione badanie zdradza liczne trudności na poziomie zarządzania zadaniem, częściowo zbliżone do tych, których doświadczaliśmy w naszym badaniu. Badacze ci koncentrują się na określeniu wartości dydaktycznej rozszerzonej sytuacji uczeniowej, definiowanej głównie poprzez potencjał proponowanego narzędzia do komunikacji asynchronicznej. OU nie dostosowali się jednak do wymogów formalnych zadania, tj. część z nich nie przystapiła do wykonania zadania online. W tej sytuacji, badacze nie mogli poprawnie określić wartości dydaktycznej zadania tym bardziej, że jego koncepcja zakładała, że interakcje uczeniowe, które rozgrywają się w przestrzeni wirtualnej obejmują wyłącznie OU, ON nie podejmuje zaś bezpośrednich interwencji. Postulowany przez badaczy kontekst zakładał powstanie sytuacji uczeniowej, w której cześć zadań zwyczajowo przypisanych nauczycielowi, powinno odbywać się w środowisku wirtualnym i spoczywać wyłącznie na wspólnej odpowiedzialności uczących się, mających wzajemne zobowiązania. Kontrola wykonania zadania nie jest już więc jedynie obowiązkiem ON. ON rezygnuje tym samym z działań interwencyjnych, pozostawiając w gestii OU dbałość o właściwą realizację polecenia zadania $\mathrm{i}-\mathrm{w}$ konsekwencji - o odpowiednią jakość tworzonego rozumowania.

Omawiane badanie pozwala zauważyć konieczność ściślejszej definicji współpracy uczniowskiej w zadaniach opartych o komunikację asynchroniczną: w omawianym projekcie Groves’a i O’Donoghue’a (2007), wymiar wspólnych działań ogranicza się do krytycznej oceny wzajemnych propozycji. Natomiast odpowiedzialność za formę zadania nie jest współdzielona, a uwagi studentów z grupy 
są traktowane jedynie jako sugestie ułatwiające pracę własną. Niską skuteczność zadania łączymy z niespójnymi oczekiwaniami OU i ON wobec celu pracy w środowisku wirtualnym. Badanie to zdaje się więc potwierdzać konieczność rozwijania u OU refleksji na temat znaczenia pracy własnej oraz na temat wartości pracy w grupie i negocjowania formy proponowanych zadań, oraz kryteriów oceny.

\section{Wniosek 2: Konieczność rozwijania umiejetności argumentacji w środowisku wirtualnym.} Konieczność uwrażliwienia OU na cele poznawcze i dialogowy wymiar interakcji

Interesującym zagadnieniem, związanym z pojęciem uczenia się we współpracy jest znaczenie argumentacyjnego wymiaru zadania typu dyskusja dla tworzenia sytuacji uczeniowej. Pomimo, że w badaniu własnym wykorzystujemy narzędzie wiki jesteśmy zdania, że oczekiwania formułowane w odniesieniu do dyskusji online dotyczą umiejętności kognitywnych, decydujących o skuteczności interakcji także na wiki, ponieważ umożliwiają utrzymanie argumentacyjnego, dialogowego wymiaru działań opartych na współdziałaniu.

Badania umieszczone w publikacji pod redakcja Deaudelin i Nault (2005) (np. Karsenti i Fortin, 2005, a także Martin, 2005) pozwalają zauważyć, że zadania dyskusji na forum może mieć różne cele. I tak, interakcja może mieć raczej wymiar wspierający, jak na przykład w badaniu Karsenti i Fortin (2005), gdzie forum jest miejscem wymiany doświadczeń i uwag, związanych z działaniami podejmowanymi przez studentów podczas praktyk nauczycielskich. Przedmiotem interakcji nie jest nabywanie wiedzy w określnym zakresie, jest nim raczej porządkowanie swoich doświadczeń. $\mathrm{Na}$ analizowanym przez autorów forum przeważają działania wspierające, mniej jest refleksji zorientowanej na cele poznawcze. OU tworzą więc raczej wspólnotę praktyków niż wspólnotę uczących się we współdziałaniu.

Jak wspomniano powyżej, wnioski formułowane przez badaczy zajmujących się obserwacją interakcji uczeniowych na forum (np. Martin 2005) zdają się potwierdzać, że budowanie interakcji zorientowanej na cele kognitywne jest związane z wieloma wyzwaniami. W swoim badaniu, gdzie forum definiowane było jako miejsce współkonstruowania treści akademickich, autorzy dochodzą do serii wniosków, które pokrywają się w dużej mierze z trudnościami zaobserwowanymi w naszym badaniu. Przede wszystkim, badacze zauważają, że w analizowanych dyskusjach na forum studenci nie realizują działań zmierzających do współkonstruowania wiedzy. Przedstawiają raczej opinie, unikając jednocześnie konfrontacji stanowisk, nie werbalizują więc rozbieżności. W swoich działaniach komunikacyjnych, studenci często przywołują swoje doświadczenia, natomiast prawie w ogóle nie odwołują się do wiedzy z dziedziny (fr. savoirs codifiés). W tej sytuacji, jak zauważają autorzy, wypowiedzi oparte na doświadczeniach osobistych czy też na nadmiernie uproszczonych uogólnieniach nie zachęcają pozostałych do argumentowania czy do dyskusji. Zauważyć należy więc rozbieżność miedzy teoretycznym ujęciem argumentacji jako zadania realizującego cele poznawcze, a reprezentacjami zadania OU, zdecydowanie nadmiernie akcentującymi wymiar interpersonalny i konwersacyjny interakcji tego typu. 
Przytoczone wnioski z lektury literatury przedmiotu akcentują konieczność prowadzenia przez nauczyciela-badacza rozbudowanej refleksji dotyczącej celów kształcenia równolegle z wdrażaniem scenariuszy hybrydowych. Jest to tym bardziej niezbędne, że jednym z podstawowych wymogów zadania online jest, by pozwalało ono realizować cele uczeniowe inaczej trudne do osiagnięcia, tj. by otwierało nowe możliwości w kształceniu instytucjonalnym. W cytowanych badaniach kluczowym problemem jest uczenie się przez dialog, które pozostaje często trudnym do zrealizowania celem dydaktycznym również w kształceniu stacjonarnym. Pomimo sygnalizowanych trudności badawczych można niemniej, na podstawie przytoczonych badań, oczekiwać że hybrydowy kontekst odpowiednio skonstruowanego zadania pozwoli lepiej uchwycić uczniowskie strategie konstruowania i współkonstruowania wiedzy i - w konsekwencji - skuteczniej definiować pożądane działania komunikacyjne i poznawcze w odniesieniu do poszczególnych etapów zadania.

\section{Podsumowanie wniosków z badania: wyzwania dla nauczyciela. Współtworzenie sytuacji uczeniowej online a rozwijanie samo- dzielności osób uczących się}

W niniejszej sekcji przedstawione zostaną wnioski podsumowujące omawiane w ramach artykułu działania badawcze. Proponowane rozumowanie miało na celu uchwycenie podstawowych pytań i problemów, formułowanych z perspektywy nauczycielabadacza, podejmującego trud konstruowania hybrydowych scenariuszy zajęć w sytuacji kształcenia językowego. Zarówno wnioski formułowane w przytaczanych badaniach, jak i te sygnalizowane w ramach badań własnych pozwalają stwierdzić, że przygotowanie i prowadzenie przez ON zadania opartego na samodzielnych działaniach OU wiąże się z licznymi wyzwaniami. Aktywność nauczyciela, wspierającego OU w działaniach zorientowanych na konstruowanie wiedzy wiąże się z umiejętnością prowadzenia refleksji w dialogu. Co więcej, takie rozumienie formy pracy w środowisku wirtualnym powinno być współdzielone z OU, ponieważ poprawne wykonanie zadania wymaga silnego zaangażowania intelektualnego wszystkich partnerów i zgody na przypisanie realizowanemu zadaniu odpowiedniego znaczenia, tj. na uznanie go za zadanie ważne, któremu należy poświęcić wspólnie wynegocjowaną ilość czasu i które powinno umożliwić realizację współdzielonych celów poznawczych.

Aby zadanie realizowane online mogło odpowiadać postulowanym przez nas celom nauczania/uczenia się, sądzimy także, że konieczne jest jasne sformułowanie celów uczeniowych, a także skorelowanie obu sytuacji dydaktycznych: działań w klasie i w przestrzeni wirtualnej. W przypadku kluczowej dla nas sytuacji uczeniowej, jaką jest rozwijanie działań argumentacyjnych na etapie przygotowania do dyskusji, ujęcie to polega, naszym zdaniem, na postrzeganiu pracy online jako etapu przygotowania, a ocena tego etapu powinna być uwzględniona przy ocenianiu zadania dyskusji, prowadzonej następnie w klasie.

Uważamy ponadto, że wiki może pomóc studentom w uświadomieniu sobie własnych działań uczeniowych oraz w ocenie ich skuteczności. Jednakże należy 
pamiętać, że wiki nie jest przestrzenia, w której moga objawić się działania uczeniowe wyższego rzędu tylko dlatego, że OU budują swoją refleksję w komunikacji asynchronicznej. Nauczyciel-tutor powinien więc zadbać, już na etapie tworzenia scenariusza dydaktycznego, o odpowiednie zdefiniowanie specyfiki wspólnej pracy na wiki, tj. o określenie głównych celów poznawczych, jakie OU powinni osiagnąć w trakcie wykonywania zadania. Należy także wspólnie określić te działania uczeniowe, które powinny wspomóc ich osiagnięcie. Scenariusz pracy powinien angażować OU w respektowanie konwencji zadania, widoczne także w prowadzeniu pracy w taki sposób, by spełniała ona wcześniej dobrane kryteria oceny. Konieczne jest także prowadzenie podsumowań po każdym proponowanym zadaniu i dbanie o ich cykliczność tak, by możliwe było wdrożenie OU do pracy w środowisku wirtualnym i tym samym doskonalenie ich strategii uczenia się, między innymi poprzez modyfikację reprezentacji dotyczących pracy na tym etapie.

Podobnie, ważnym elementem skutecznej pracy ON wydaje się prowadzenie dzienniczka badania, w którym ON regularnie odpowiada na sformułowane wcześniej pytania badawcze tj. w którym dąży do określenia związków miedzy etapem pracy samodzielnej OU a rozwijaniem sprawności mownych. Dzienniczek może stać się narzędziem sprzyjającym porządkowaniu obserwacji dotyczącej współtworzonego i współzarządzanego wydarzenia komunikacyjno-uczeniowego jakim jest etap pracy na wiki. Krytyczna ocena sytuacji i jej regularne monitorowanie poprzez prowadzenie notatek wydają się niezbędne w kontekście badania w działaniu, kiedy to nauczyciel prowadzący zajęcia sam wprowadza innowację dydaktyczną.

\section{BIBLIOGRAFIA}

Bélisle, C. 2010. „Les technologies: quels usages, pour quels effets?” [w:] Charlier, B. i Henri, F. (red.). Apprendre avec les technologies. Paris: PUF. 35-45.

Burton, R. i in. 2011. „Vers une typologie des dispositifs hybrides de formation en enseignement supérieur". [w:] Distances et savoirs 9: 69-96.

Celik, C. 2008. „Analyse de pratiques de tutorat dans un campus numérique de maîtrise de français langue étrangère à distance". [w:] Apprentissage des Langues et Systèmes d'Information et de Communication (Alsic) 11: 93-119. (http://alsic.revues.org/index833.html) [DW: 27.11.2011].

Charlier, B., Deschryver, N. i Peraya, D. 2006. „Apprendre en présence et à distance. Une définition des dispositifs hybrides". [w:] Distances et savoirs 4: 469-496.

Chen, D.-T., i Hung, D. 2002. „Personalised knowledge representations: the missing half of online discussions". [w:] British Journal of Educational Technology 33: 279-290.

Daele, A. i. Docq, F. 2002. „Le tuteur en ligne, quelles conditions d'efficacité dans un dispositif d'apprentissage collaboratif à distance?" [w: Actes du $19 e$ Colloque de l'AIPU, Louvain-la-Neuve, mai 2002. (9 stron). http://www.ipm.ucl.ac.be/ articlesetsupportsIPM/DocqDaeleAIPU2002.pdf [DW: 30.11.2011] 
Degache, Ch. i Nissen, E. 2008. „Formations hybrides et interactions en ligne du point de vue de l'enseignant: pratiques, représentations, évolutions". [w:] Apprentissage des Langues et Systèmes d'Information et de Communication (Alsic) 11: 61-92. (http://alsic.revues.org/index797.html) [DW: 30.11.2011].

Ellis, R. A., Goodyear, P., Prosser, M. i O’Hara, A. 2006. „How and what university students learn through online and face-to-face discussion: conceptions, intentions and approaches". [w:] Journal of Computer Assisted Learning 22: 244-256.

Gajek, E. 2008. Edukacja jezy/kowa w społeczeństwie informacyjnym. Warszawa: Instytut Lingwistyki Stosowanej UW.

Górecka, J. 2009. „Wprowadzanie elementów nauczania hybrydowego w kształceniu językowym; uzasadnienie dydaktyczne oraz główne wyzwania dla nauczyciela". [w:] Neofilolog 33: 41-52.

Groves, M. i O'Donoghue, J. 2009. „Reflections of students in their use of asynchronous online seminars". [w:] Educational Technology \& Society 12. 143-149.

Hanna, B. E. i de Nooy, J. 2009. Learning language and culture via public Internet discussion forums. Basingstoke; New York: Palgrave Macmillian.

Karsenti, T. i Fortin, T. 2005. „Collaboration par les TIC. Nouveau défi de la formation pratique?" [w:] Deaudelin, C. i Nault, T. (red.). Collaborer pour apprendre et faire apprendre. La place des outils technologiques. Sainte-Foy, Québec: Presses de l'Université du Québec. 81-101.

Krajka, J. (2012). The language teacher in the digital age - towards a systematic approach to digital teaching development. Lublin: Wydawnictwo UMCS.

Mangenot, F. i Penilla, F. 2009. „Internet, tâches et vie réelle”. [w:] Le Français dans le monde, Recherches et applications 45. Paris: CLE International. 82-90.

Martin, D. 2005. „Forum de discussion en formation des maitres. Apprentissage de la délibération collégiale". [w:] Deaudelin, C. i Nault, T. (red.). Collaborer pour apprendre et faire apprendre. La place des outils technologiques. Sainte-Foy, Québec: Presses de l'Université du Québec. 103-119.

Meyer, K. A. 2006. ",The method (and madness) of evaluating online discussions”. Journal of Asynchronous Learning Networks 10: 83-97. (http://www.aln.org/ publications/jaln/v10n4/pdf/v10n4_meyer1.pdf) [DW: 30.11.2011].

Palloff, R. M. i Pratt, K. 2007. Building online learning communities. Effective strategies for the virtual classroom. San Francisco: Wiley.

Soubrié, T. 2008. „La difficile articulation du présentiel et de la distance dans le cadre d'un cours hybride en master". [w:] Apprentissage des Langues et Systèmes d'Information et de Communication (Alsic) 11: 105-126. (http://alsic. revues.org/index385.html) [DW: 30.11.2011].

Walckiers, M. i de Praetere, T. 2004. „L'apprentissage collaboratif en ligne, huit avantages qui en font un must'. [w:] Distances et savoirs 2. 53-75.

Weasenforth, B., Biesenbach-Lucas, S. i Meloni, Ch. 2002. „Realizing constructivist objectives through collaborative technologies; threaded discussions". [w:] Language Learning \& Technology 6: 58-86. (http://llt.msu.edu/vol6num3/ weasenforth/) [DW: 30.11.2011]. 